\title{
Penguatan Kewilayahan dengan Pemetaan Keunggulan Potensi Daerah di Era New Normal
}

\author{
Ni Ketut Sari Adnyani \\ niktsariadnyani@gmail.com \\ Universitas Pendidikan Ganesha
}

\begin{abstract}
The Covid-19 pandemic has had an impact on decreasing state opinion, increasing the poverty rate under various economic growth scenarios, and the people's income has fallen sharply. Welcoming the New Normal is an agenda for related stakeholders to review governance, health security, including social capital built on the basis of consensus, values and morals, and carrying capacity through collaborative networks that promote mutual synergy between the state, the private sector and the community. This article aims to examine strategies for restoring regional strengthening by mapping regional potential excellence in the new normal era; and draft policies for strengthening areas and mapping of regional potentials. Qualitative method with literature study analyzed descriptively. The results showed that the post-recession national economic recovery strategy still requires more time. The draft of regional strengthening policies and mapping of heterogeneous regional potentials becomes a policy approach to respond to community-based economic needs that reflect economic democracy by involving customary instruments as a form of further policy realization. Access to information transparency needs to be optimized through virtual media to make it easier for researchers, the public, academics, and practitioners to access the latest information.
\end{abstract}

Keywords : new normal, regional potential, territorial strengthening

\section{Pendahuluan}

Menurut Vivian Balakrishnan dikutip Modjo (2020), bahwa ketahanan suatu bangsa dalam menghadapi Pandemi Covid-19 sangat ditentukan oleh kesigapan negara bersangkutan melakukan penanganan dilihat perspektif ketahanan kesehatan publik, modal sosial serta sistem tata kelola pemerintahan. Bersinergi dengan sistem tata kelola pemerintahan untuk membangkitkan kembali tatanan kehidupan sosial ekonomi warga, perlu dibangun kepercayaan, penanaman nilai atau moral bersama dan membentuk jejaring kerjasama sebagai wujud pengaplikasian modal sosial. Ketiga komponen tersebut merupakan aspek-aspek yang dinilai produktif untuk diibangkitkandan bentuk perealisasiannya dapat dilaksanakan secara bertahap dengan tetap memperhatikan protokol kesehatan. Bercermin dari problematik sendi-sendi kehidupan bernegara akibat pandemic Covid-19 berdampak rentan terhadap penurunan kinerja ekonomi global, termasuk Indonesia.

Mengantisipasi penyebaran dampak virus Covid-19, Presiden Republik Indonesia, Joko Widodo menetapkan Pembatasan Sosial Berskala Besar (PSBB). Kebijakan PSBB berdasarkan Peraturan Pemerintah Nomor 21 tahun 2020 dengan berpedoman pada Pasal 60 Undangundang Nomor 6 Tahun 2018 tentang Karantina Kesehatan yang diberlakukan sejak tanggal 9 Maret 2020 (Indonesia, 2018). Langkah ini ditempuh berlandaskan pertimbangan epidemologis, sumber daya, ekonomi, sosial dan budaya, keamanan, dan besarnya ancaman terhadap efektifitas berbagai sektor kehidupan bermasyarakat, berbangsa, dan bernegara (Nasional Kompas. (2020)). Kebijakan PSBB berfungsi sebagai social control dalam memutus mata rantai penyebaran virus covid-19. Implikasi pandemi covid-19 di bidang perekonomian khususnya bagi para pelaku usaha dan masyarakat lainnya yang menyebabkan sejumlah industri mati dan mata pencaharian menjadi tersendat bagi masyarakat yang bekerja disektor informal (Media, 7 April 2020). 


\section{Kajian Pustaka}

Berkenaan dengan dampak pandemic Covid-19, frediksi bank dunia terhadap Indonesia terkait pengaruh resensi global 2020, yaitu resiko paling besar adalah distribusi modal dari pasar keuangan, diperkirakan memiliki potensi peluang kembali meskipun porsinya lebih kecil. Dampaknya relatif terkendali untuk rentang waktu jangka pendek. Dampak jangka menengah, justru dapat menurun jika tidak dimitigasi berpotensi melemah hingga $\pm 4,6$ persen pada 2021 (Adiyanta, 2020). Kondisi fluktuatif perekonomian nasional, secara lebih rinci dapat dicermati dari sektor penerimaan pendapatan negara dalam anggaran pendapatan dan belanja negara (APBN) 2020 menjadi salah satu yang terkena dampak. Hasil rilis laporan bulan Juli 2020, capaian pendapatan negara Indonesia terkumpul dalam kisaran $\pm 922,2$ triliun. Penurunan sejumlah $\pm 12,4 \%$ dari realisasi pada periode yang sama di tahun sebelumnya berada dalam rentang \pm Rp.1.052,4 triliun. Di satu sisi, penerimaan pajak juga mengalami penurunan sebesar $\pm 12,3 \%$, dan PNBP turun sejumlah $\pm 13,5 \%$. Di sisi lain peningkatan signifikan sebesar $\pm .561,6 \%$ dari \pm Rp 371,8 triliun pada Januari-Juli 2019 menjadi \pm Rp 2.460 triliun terjadi terhadap pendapatan negara pada tiga aspek, seperti: penerimaan perpajakan, penerimaan negara bukan pajak (PNBP), dan hibah (Dwi Hadya Jayani, 2020). Grafik pemetaan pendapatan negara periode Januari- Juli 2019 dan 2020 dapat dilihat pada gambar 1. berikut:

\section{Gambar 1. Pendapatan Negara Periode Januari- Juli 2019 dan 2020}

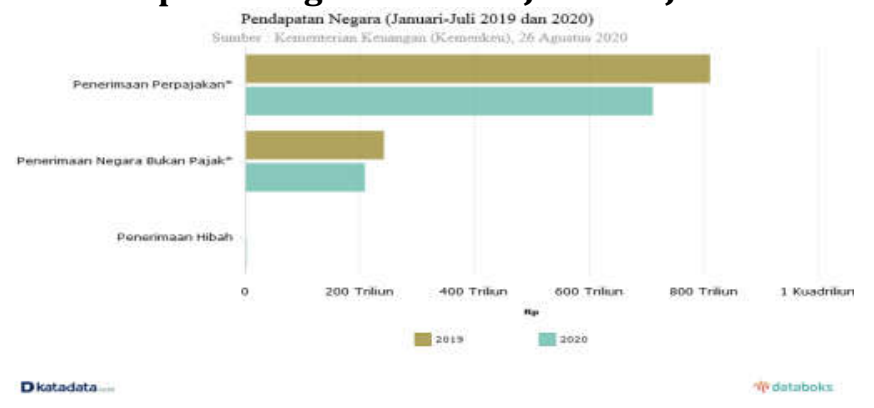

Sumber: Jayani (2020)

Berdasarkan data yang terangkum dalam gambar 1. di atas, menunjukkan negara Indonesia tengah menghadapi permasalahan pendapatan perkapita dimana terjadi penurunan drastis akibat pandemic Covid-19. Permasalahan serupa juga terjadai di bidang pemenuhan taraf kesejahteraan bagi setiap warga negara yang menjadi sektor paling berdampak. Strategi seperti ini disusun sebagai terobosan terhadap data skenario pertumbuhan ekonomi yang disandingkan dengan angka kemiskinan nasional. Sejumlah 8 (delapan) buah skrenario yang beragam dieksplore. Skenario pertama, muncul dari Kementerian Keuangan sebesar \pm 1 persen. Skenario kedua, datang dari Bank Dunia sebesar \pm 0 persen. Skenario ketiga, dipublish menurut simulasi Lembaga Penyelidikan Ekonomi dan Masyarakat Universitas Indonesia (LPEM UI) dengan adanya stimulus fiscal. Skenario keempat berdasarkan International Monetary Fund (IMF) dengan perkiraan $\pm-0,3$ persen. Skenario kelima, muncul dari Kementerian Keuangan senilai $\pm-0,4$ persen. Skenario keenam, berdasarkan simulasi LPEM UI tanpa stimulus fiskal. Skenario ketujuh, dan delapan datang dari Organisation for Economic Co-operation and Development (OECD) senilai $\pm-2,8$ persen dan $\pm-3,9$ persen. Angka kemiskinan tertinggi berada pada $\pm 11,69$ persen dengan jumlah orang miskin sebanyak $\pm 31,57$ juta jiwa (Hanna Farah Vania, 2020). Angka kemiskinan dengan beragam skenario pertumbuhan ekonomi dapat dilihat pada gambar 2. Berikut. 


\section{Gambar 2. Angka Kemiskinan dengan Beragam Skenario Pertumbuhan Ekonomi}

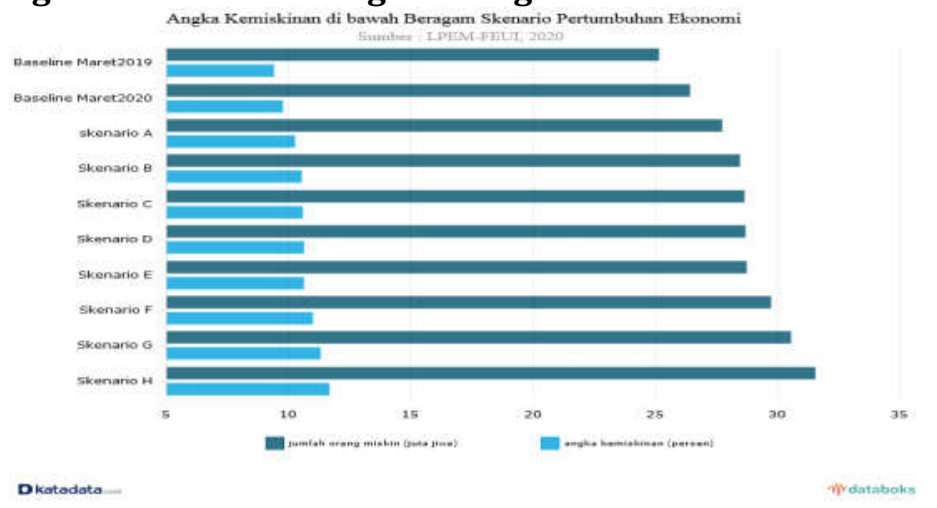

Sumber : Lidwina (2020)

Berpedoman pada rujukan data gambar 2. di atas, menunjukkan terhambatnya pertumbuhan ekonomi Indonesia pada tahun 2020, angka prosentase yang tercover di masingmasing level skenario terkoreksi sebagai dampak pandemi Covid-19, dan sebagian kalangan memprediksikan pertumbuhan mengalami penurunan. Lemahnya ekonomi nasional juga dapat diitinjau dari segi pendapatan yang mengalami penurunan. Sebanyak $\pm 70 \%$ responden mengatakan pendapatan kotor rumah tangganya turun dalam satu bulan terakhir akibat pandemi Covid-19. Sementara itu, sisanya masih punya pendapatan yang sama $( \pm 27 \%)$, bahkan ada yang mengalami kenaikan $( \pm 1 \%)$. Saiful Mujani Research and Consulting (SMRC) melakukan survei ini terhadap $\pm 1,2$ ribu responden yang tersebar di \pm 34 provinsi di Indonesia pada 9-12 April 2020 (Andrea Lidwina, 17 April 2020). Dampak pandemic covid-19 terhadap pendapatan masyarakat di Indonesia dapat dicermati pada gambar 3. Berikut.

\section{Gambar 3. Dampak Covid-19 terhadap Penghasilan Masyarakat Pendapatan Masyarakat selama Pandemi Covid-19 (Survei SMRC)

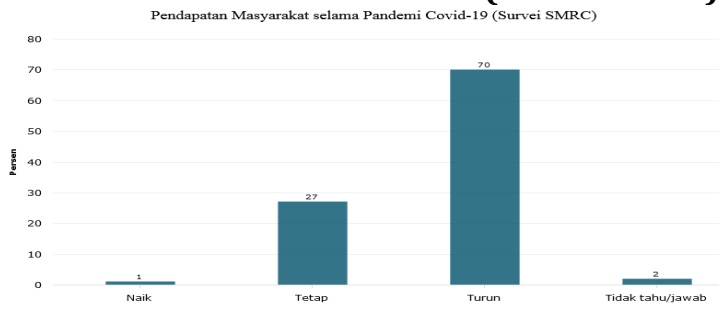

Sumber: Lidwina (2020)

Berdasarkan data pada gabar 3. di atas, menunjukkan bahwa pemasukan penghasilan masyarakat mengalami penurunan drastis. Fenomena ini menandakan bahwa kontraksi perekonomian global berpengaruh terhadap kondisi perekonomian nasional di Indonesia. Menurunnya penghasilan masyarakat membawa imbas tidak hanya secara ekonomi tapi juga secara sosial, munculnya stratifikasi kelas disebabkan oleh melonjaknya angka pengangguran imbas pandemic Covid-19 menjadi problem yang urgen untuk sesegera mungkin direspon oleh pemerintah.

Dimulainya babakan baru menata kembali tatanan perekonomian Indonesia. Kenyataannya dihadapkan dengan kondisi kesehatan yang belum memadai, dengan dibukanya kelonggaran pembatasan sosial di berbagai daerah dinilai beresiko, namun menyongsong new normal merupakan sebuah keharusan. Terlebih eksistensi Indonesia yang selama ini sudah mencapai status berada di level negara dengan kapasitas berpendapatan menengah-tinggi terancam runtuh justru harus bangkit seperti kondisi 10-20 tahun lalu (Sumner, A., Hoy, C. and Ortiz-Juarez, 2020); (Asep Suryahadi, Ridho Al Izzati, 2020). Di tataran praktik, sektor yang 
dinilai paling terdampak seperti pariwisata, transportasi, perdagangan dan menjadi prioritas untuk dipulihkan. Kajian kebijakan yang ditunggu adalah bagaimana mekanisme pemulihan dan periode yang dibutuhkan (Wardhana, 2020). Melalui rancangan kebijakan yang direkomendasikan untuk digagas merespon permasalahan perekonomian nasional yang fluktuatif, mengadopsi pandangan (Mohamad Ikhsan Modjo, 2020) menjadi sebuah kesempatan untuk melakukan penguatan ekonomi asalkan diiringi penyusunan prioritas yang transparan serta koordinasi dan sinkronisasi kebijakan yang tepat.

Rendahnya pertimbangan aspek ekonomi menjadi prioritas agenda yang penting dirujuk untuk penguatan wilayah adalah suatu kenyataan, termasuk pemetaan potensi di masing-masing daerah di seluruh wilayah Indonesia. Hal ini sesuai dengan Teori Mesin Pertumbuhan (Growth Machine Theory) yang dikemukan (Molotch, 1976), menguraikan alasan dari pertumbuhan wilayah adalah koalisi antara politik lokal dan elite ekonomi. Dalam teori ini, dorongan untuk mengejar strategi pertumbuhan wilayah datang bukan dari kekuatan struktural ekonomi atau dari tendesi keseimbangan yang dihasilkan oleh eksport dan perdagangan. Sebagai penggantinya, datang dari koalisi politik dari elite (birokrasi) yang siap berperan serta membangkitkan kembali segmen ekonomi lokal (Dawkins., 2003).

Selanjutnya dalam rangka memetakan agenda kebijakan pemulihan perekonomian dalam negeri, ditambahkan oleh Akhmad (2007), mengutip makalah Musser, G. (2005), menyebutkan bahwa abad ke 21 sebagai "one of the most amazing periods in human history". Karakteristik abad 21 ditandai dengan adanya tiga transisi besar yang digerakkan sebelumnya oleh revolusi industri dicapaian titik puncak. Muatan substansi tiga transisi disinyalir dapat menopang pertumbuhan ekonomi Indonesia yang mana saling berinteraksi dan berjalan bersamaan antara lain: demografi, ekonomi, serta sumberdaya alam dan lingkungan. Ketiganya telah terinternalisasi hampir di semua aspek dari mulai geopolitik sampai struktur rumah tangga. Di sisi lain transisi pasca pandemic Covid-19 telah membawa kebiasaan baru yang tidak pernah dirasakan oleh umat manusia sebelumnya.

Merespon keseluruhan permasalahan risk economy di atas, dibutuhkan strategi peningkatan berusaha dan daya saing ekonomi Indonesia dalam rangka menata kembali perekonomian nasional pasca pandemic Covid-19. Mewujudkan pembangunan ekonomi di era new normal diperlukan rancangan kebijakan yang dapat menyasar berbagai aspek perubahan dalam kegiatan ekonomi, karena pada dasarnya ukuran taraf pembangunan ekonomi yang dicapai suatu negara tidak mudah diukur secara kuantitatif (Sukirno, 2006). Arah kebijakan yang dimaksudkan adalah menyasar penyelenggaraan tata kelola pemerintahan yang mampu mensinergikan ketahanan kesehatan dan modal sosial pada ranah pembangunan secara umum dengan maksud sebagai upaya pencapai dan peningkatan kesejahteraan ekonomis bagi seluruh rakyat Indonesia (Anwas, 2014). Kebijakan yang digagas dinilai penting mengadopsi prinsip pembangunan berkelanjutan dengan mengusung sinergi mutual antara aspek ekonomi, sosial budaya secara demografi, dan ekologi.

Dalam menindaklanjuti perbaikan tatanan kehidupan perekonomian dalam negeri, tepat merujuk Teori pertumbuhan ekonomi. Teori ini dikemukakan oleh Harry W Richardson (1972) dalam bukunya, "Regional Economic Growth" dan dipopulerkan oleh Molotch (1976); (Soepono, 2001). Teori ini memetakan tiga segmen kewlayahan, seperti pertumbuhan suatu wilayah tergantung pada faktor tenaga kerja, faktor ketersediaan modal dan faktor kemajuan teknologi wilayah tersebut. Sebagai stabilitator menciptakan sebuah keseimbangan pertumbuhan antar wilayah, negara berkapasitas sebagai penyeimbang antara dunia usaha dan masyarakat. Dikaitkan dengan salah satu hal yang ditekankan pada teori ini adalah mobilitas faktor produksi, terutama tenaga kerja dan investasi antar wilayah, dan negara. Teori ini dijadikan rujukan dalam rancangan kebijakan penguatan wilayah dengan alasan teori ini dapat diterapkan dalam mengidentifikasi pertumbuhan wilayah yang didukung oleh adanya tingkat kekuatan teknologi dan inovasi yang ada pada wilayah terlebih ketika dihadapkan dengan sejumlah penyesuaian pada pasca pandemic covid-19. 
Menjadi penting kembali mengedepankan nilai-nilai luhur Pancasila. Landasan kebijakan ekonomi Indonesia pasca pandemic covid-19 juga penting menjadikan Pancasila sebagai pedoman sekaligus landasan idiil kehidupan berbangsa dan bernegara dan UUD NRI Tahun 1945 sebagai landasan konstitusional (UUD NRI 1945). Landasan idiil Pancasila dijadikan pedoman penyusunan kebijakan nasional melalui internalisasi sila-sila Pancasila disetiap rujukan substansi pengaturan bidang perekonomian yang hendak disusun (Hafizah, 2005). Pandemi Covid-19 telah menyebabkan menurunnya perekonomian dan aktivitas di berbagai sektor dan wilayah di Indonesia. Modjo (2020) melakukan pemetaan jalan menuju penguatan ekonomi untuk menyosong era new normal sehingga perbaikan tatanan perekonomian nasional direncanakan secara bertahap.

Mulyana (2020) berpandangan bahwa dalam menghadapi penyesuaian kondisi ekonomi yang kurag stabil penting direkomendasikan model pembangunan ekonomi dengan berpedoman pada Proyek Prioritas Strategis (Major Project) dalam RPJMN 2020-2024 yang akan menjadi fokus dalam rencana dan anggaran RKP (Negara Republik Indonesia, 2004). Prioritas strategis ini dipertimbangkan dapat mempercepatan pemulihan ekonomi tergantung kepada kombinasi kebijakan yang pas antara kebijakan pemutusan sebaran virus (virus containment secara maksimum) dan kebijakan ekonomi (intervensi kebijakan ekonomi yang maksimum). Mengulas kasus yang sama tentang dampak perekonomian akibat pandemic Covid-19 dengan pendekatan berbeda, Widyastuti \& Nugroho (2020) menganalisis dampak Covid-19. Jenis rekomendasi yang ditawarkan adalah pentingnya membangun strategic oil reserves di Indonesia.

Berdasarkan rujukan sejumlah tinjauan pustaka di atas, pada dasarnya kajian tentang dampak pandemi telah diulas oleh peneliti sebelumnya yang berimplikasi terhadap penurunan perekonomian nasional. Signifikasi perbedaan dari makalah ini dengan kajian sebelumnya yaitu fokus kajian lebih menekankan pada rancangan kebijakan penguatan wilayah dengan pemetaan keunggulan potensi daerah dalam tata kelola pemerintahan, modal sosial, dan pertimbangan prosedur protokol kesehatan. Rancangan kebijakan juga bersendikan pendekatan pembangunan berkelanjutan sehingga selaras antara aspek ekonomi, sosial budaya, dan ekologi.

\section{Metodologi Penelitian}

Melakukan penelusuran terhadap sejumlah permasalahan dampak perekonomian nasional saat pandemic Covid-19 sebagai rujukan untuk merancang kebijakan penguatan ekonomi wilayah pasca covid-19, makalah ini sangat tepat menggunakan metode kualitatif. Penelitian kualitatif berfokus pada latar secara alamiah dengan maksud menerjemahkan fenomena yang terjadi melalui metode yang ada (Moleong, 2009). Metode kualitatif dengan studi pustaka lebih relevan dibandingkan dengan studi lapangan mengingat kondisi pandemi virus Covid-19 penting memperhatikan anjuran protocol kesehatan dan PSBB secara keseluruhan belum sepenuhnya dibuka. Dengan penelusuran melalui media literatur untuk pemanfaatan media virtual sekarang ini, akurasi data juga sudah tersedia dalam situs layanan laporan sejumlah kementerian dan lembaga indeks.

Penelitian kualitatif ini bersifat studi pustaka yang menggunakan buku dan literatur lainnya sebagai objek utama. Kysh (2013), berpendapat bahwa telaah literatur bertujuan untuk membuat kesimpulan dan evaluasi pada suatu topik tertentu. Sumber data diperoleh dari jurnal ilmiah, buku, media massa, laporan perkembangan kasus perekonomian di tengah masa pandemi Covid-19 di Indonesia. Selain itu juga dengan melakukan pembacaan terhadap kebijakan atau regulasi dan laporan-laporan. Data dikumpulkan kemudian data dianalisis dengan menggunakan teori hingga diperoleh kesimpulan.

\section{Analisis dan Pembahasan}

\subsection{Analisis Literatur}

Melakukan penelusuran terhadap sejumlah permasalahan dampak perekonomian nasional saat pandemic Covid-19 sebagai rujukan untuk merancang kebijakan penguatan ekonomi wilayah pasca covid-19, makalah ini sangat tepat menggunakan metode kualitatif. Penelitian kualitatif berfokus pada latar secara alamiah dengan maksud menerjemahkan fenomena yang terjadi melalui metode yang ada (Moleong, 2009). 
Metode kualitatif dengan studi pustaka lebih relevan dibandingkan dengan studi lapangan mengingat kondisi pandemi virus Covid-19 penting memperhatikan anjuran protocol kesehatan dan PSBB secara keseluruhan belum sepenuhnya dibuka. Dengan penelusuran melalui media literatur untuk pemanfaatan media virtual sekarang ini, akurasi data juga sudah tersedia dalam situs layanan laporan sejumlah kementerian dan lembaga indeks.

Penelitian kualitatif ini bersifat studi pustaka yang menggunakan buku dan literatur lainnya sebagai objek utama. Kysh (2013) berpendapat bahwa telaah literatur bertujuan untuk membuat kesimpulan dan evaluasi pada suatu topik tertentu. Sumber data diperoleh dari jurnal ilmiah, buku, media massa, laporan perkembangan kasus perekonomian di tengah masa pandemi Covid-19 di Indonesia. Selain itu juga dengan melakukan pembacaan terhadap kebijakan atau regulasi dan laporan-laporan. Data dikumpulkan kemudian data dianalisis dengan menggunakan teori hingga diperoleh kesimpulan.

\subsection{Stategi Pemulihan Penguatan Kewilayahan Degan Pemetaan Keuaggulan Poteni Daerah Di Era New Normal}

Tersusunnya perencanaan pembangunan desa terpadu berbasis tata ruang dan kewilayahan terkait dengan pemetaan komoditas unggulan secara partisipatif dan terdokumentasikan dengan baik sekaligus memperkuat kapasitas aparat pemerintahan daerah dalam kerangka:

a. Melindungi dan memperluas ruang otonomi dan kebebasan masyarakat,

b. Membatasi kekuasaan (kewenangan dan intervensi) pemerintah daerah dan pusat, serta melindungi hak-hak prakarsa masyarakat daerah,

c. Menjamin kekebasan masyarakat daerah,

d. Melindungi dan membela kelompok yang lemah di daerah,

e. Menjamin partisipasi dalam proses pengambilan keputusan antara lain, dengan memastikan bahwa masyarakat daerah terwakili kepentingannya dalam BPD, dan

f. Memfasilitasi perbaikan dan pengembangan kondisi sosial politik-ekonomi masyarakat daerah.

Pengembangan wilayah perlu dilakukan dalam perencanaan dalam dalam skala nasional untuk mendorong pertumbuhan ekonomi lokal dan memperkuat masyarakat di lapisan bawah agar dapat mempengaruhi pasar secara berkelanjutan.

\subsection{Rancangan Kebijakan Penguatan Wilayah dan Pemetaan Potensi Daerah}

Rancagan kebijakan peguata wilayah dan pemetaan potesi daerah, diorientasikan denga dukungan dimilikinya kemampuan teknis dan pemahaman komperhensif mengenai perencanaan pembangunan desa terpadu berbasis tata ruang dan kewilayahan. Penguatan kapasitas aparatur pemerintahan daerah untuk menyusun perencanaan daerah terpadu menggunakan pendekatan kewilayahan sangat dibutuhkan untuk mendukung pengelolaan daerah unggulan.

Pedoman dalam menentukan kebijakan pengembangan daerah unggulan. Model perencanaan kebijakan partisipatif pembangunan daerah dengan mempertimbangkan aspekaspek tata ruang dan kewilayahan ini diharapkan dapat diimplementasikan untuk menyusun perencanaan yang dibuat di tingkat lokal secara strategis terintegrasi dengan rencana pengembangan antar desa, antar daerah dan pada tingkat nasional. Penguatan kesadaran hukum stakeholders ekonomi daerah dalam pengelolaan komoditas unggulan. Pengembangan wilayah dikembangkan dari kebutuhan suatu daerah untuk meningkatkan fungsi dan perannya dalam menata kehidupan sosial, ekonomi, budaya, pendidikan dan kesejahteraan masyarakat.

Rencana strategis daerah dalam penguatan wilayah adalah sebagai :

a. Penyusunan Renstra masig-masing daerah yaitu adanya komitmen dari aparat daerah.

b. Penyusunan tujuan pembagunan.

c. Pembuatan Renstra dikerjakan secara bersama oleh seluruh komponen di masyarakat. 


\section{Kesimpulan dan Rekomendasi}

Penguatan kewilayahan penting menjadi rujukan substansi kebijakan dalam tata kelola pemerintahan, yang mengepankan modal sosial dan ketahanan kesehatan. Potensi sumberdaya, pemberdayaan berbasis masyarakat, termasuk sinergi mutualyang dibangun antara negara, swasta dan masyarakat sangat mendukung produktifitas prospek ekonomi produktif yang dibangun melalui pluralisme kewilayahan dengan mempertimbangkan kearifan desa adat, emansipasi termasuk juga ekologi.

Berdasarkan pemahaman mengenai dampak Covid-19 terhadap kondisi resesi perekonomian global berimbas pada fluktuasi perekonomian nasional, dalam makalah ini diusulkan beberapa rekomendasi kebijakan diantaranya: penyusunan prioritas kebijakan ini ke depan penting disempurnakan dengan disusun secara lengkap. Pemanfaatan media virtual sebagai wujud alih fungsi teknologi berbasis data penting ditungkatkan sehingga mempermudah layanan akses informasi bagi publik. Penyusunan rancangan kebijakan mutlak memperhatikan aspek kewilayahan, melihat segmen problematika ketatanegaraan NKRI sangat kompleks dan beragam. Studi komparatif antar negara dan daerahjuga penting sebagai media perbendaharaan pengetahuan untuk dapat keluar dari problem resesi ekonomi pasca pandemic Covid-19.

Upaya pemerintah dalam menyikapi tuntutan peningkatan produktivitas daya saing nasional maupun daerah yang mensyaratkan kapasitas inovatif adalah dengan mengeluarkan Peraturan Bersama Menteri Riset dan Teknologi Nomor 3 Tahun 2012 dan Menteri Dalam Negeri Republik Indonesia dan Nomor 36 Tahun 2012 tentang Penguatan Sistem Inovasi Daerah(Negara Republik Indonesia, n.d.). Melalui peraturan bersama tersebut diamanatkan kepada semua pemerintah provinsi dan kabupaten/kota menetapkan Kebijakan Penguatan Sistem Inovasi Daerah (SIDa).

Upaya untuk menumbuh kembangkan suatu jaringan yang akan meningkatkan keunggulan komparatif daerah menuju keunggulan kompetitif dengan daya saing berbasis inovasi di daerah. Fungsinya sebagai salah satu masukan dalam peningkatan kapasistas pemerintah daerah dan daya saing daerah daerah, menjadi salah satu masukan dalam penyusunan maupun perubahan RKPD dan RPJMD.

Arah pembangunan daerah dalam hal pengembangan potensi-potensi lokal dengan mengutamakan penumbuhkembangan inovasi oleh institusi-institusi pemerintah daerah baik secara sektoral maupun lintas sektor, oleh lembaga kelitbangan, lembaga pendidikan, lembaga penunjang inovasi, dunia usaha serta masyarakat di daerah. Didukung oleh program peningkatan penguatan Sumberdaya Manusia di kawasan ini di bidang pengelolaan potensi masing-masing di wilayah Indonesia. Fokus wilayah pengembangan dalam program SIDa di masing-masig daerah diagendakan menggunakan sistem zonasi.

\section{Daftar Pustaka}

1945, U. N. R. I. T. Negara Republik Indonesia. , (1945).

Adiyanta, F. C. S. (2020). Dampak Covid 19 relatif terkendali untuk rentang waktu jangka pendek. Administrative Law \& Governance Journal, 1(2), 165-181.

Akhmad., F. (2007). Economic Of Matures Non-Convexity. Reorientasi Pembangunan Ekonomi Sumberdaya Alam dan Implikasinya Bagi Indonseia.

Andrea Lidwina, E. S. F. (n.d.). Dampak Covid-19 terhadap Penghasilan Masyarakat Pendapatan Masyarakat selama Pandemi Covid-19 (Survei SMRC), Saiful Mujani Research and Consulting (SMRC).

Anwas, M. (2014). Pemberdayaan Masyarakat Di Era Global. Bandung: Alfabeta.

Asep Suryahadi, Ridho Al Izzati, and D. S. (2020). Compared to the baseline projection of 5 percent economic growth in 2020, various studies estimate.

Dawkins., C. J. (2003). Regional Development Theory: Conceptual Foundations. Journal of Planning Literature, 18(2), :131-172.

Dwi Hadya Jayani, E. S. F. (2020). Pendapatan negara periode Januari-Juli 2019 dan 2020. 
G., M. (2005). Flaw of averages. Is ordinary matter causing the cosmos to accelerate? Scientific American, 18(9), 293.

Hafizah, Y. (2005). Kebijakan Ekonomi Indonesia Ditinjau dari Konsep Dasar Ekonomi Islam. Millah: Jurnal Studi Agama, 4(2), 31-46.

Hanna Farah Vania, E. P. I. (2020). kemiskinan dengan beragam skenario pertumbuhan ekonomi.

Indonesia, N. R. Undang-undang Nomor 6 Tahun 2018 tentang Karantina Kesehatan. , (2018).

Jayani, D. H. (2020). Pendapatan Dalam Negeri Turun, Hibah Naik 562 \% Hingga Juli 2020. 2020.

Kysh, L. (2013). What's in a name?: The difference between a systematic review and a literature review and why it matters. Medical Library Group of Southern California \& Arizona (MLGSCA) and the Northern California and Nevada Medical Library Group (NCNMLG). https://doi.org/https://doi.org/10.6084/m9.figshare.766364

Lidwina, A. (2020). Dampak Covid-19 Terhadap Penghasilan Masyarakat. Databoks.Katadata.Co.Id, (April), 2020.

Media, A. D. efek-samping-psbb-terhadap-masyarakat.

Modjo, M. I. (2020). Memetakan Jalan Penguatan Ekonomi Pasca Pandemi. The Indonesian Journal of Development Planning, 4(2), 103-116.

Modjo, Mohamad Ikhsan. (2020). Memetakan Jalan Penguatan Ekonomi Pasca Pandemi. The Indonesian Journal of Development Planning, 4(2), 104.

Moleong, L. J. (2009). Metodologi Penelitian Kualitatif. Bandung: Remaja Rosda Karya.

Molotch, H. (1976). The City as a Growth Machine: Toward a Political Economy of Place. Source: American Journal of Sociology, 82(2), September 1976.

Mulyana, Y. (2020). Peranan Ekonomi Pembangunan Pasca COVID 19. PRISMAKOM, 17(1), 3745.

Nasional Kompas. (2020, M. 20). (2020). Rekap Data Kasus Positif Covid Selama 4 Pekan.

Negara Republik Indonesia. Peraturan Bersama Menteri Riset dan Teknologi Nomor 3 Tahun 2012 dan Menteri Dalam Negeri Republik Indonesia dan Nomor 36 Tahun 2012 tentang Penguatan Sistem Inovasi Daerah.

Negara Republik Indonesia. Undang-Undang Republik Indonesia Nomor 25 Tahun 2004 tentang RPJMN IV tahun 2020 - 2024, (Lembaran Negara Republik Indonesia Tahun 2004 Nomor 47, Tambahan Lembaran Negara Nomor 3489). , Pub. L. No. Undang-Undang Republik Indonesia Nomor 25 Tahun 2004 tentang RPJMN IV tahun 2020 - 2024, (Lembaran Negara Republik Indonesia Tahun 2004 Nomor 47, Tambahan Lembaran Negara Nomor 3489). (2004).

Soepono, P. (2001). Teori Pertumbuhan Berbasis Ekonomi (Ekspor): Posisi dan Sumbangannya Bagi Perbendaharaan Alat-alat Analisis Regional. Journal of Indonesian Economy and Business, 16(1), 41.

Sukirno, S. (2006). Ekonomi Pembangunan. Jakarta: Putra Grafika.

Sumner, A., Hoy, C. and Ortiz-Juarez, E. (2020). Estimates of the impact of COVID-19 on global poverty. 2020/43. Helsinki.

Wardhana, D. (2020). Kajian Kebijakan dan Arah Riset Pasca-Covid-19. The Indonesian Journal of Development Planning, 4(2), 223-239. (227).

Widyastuti, N. L., \& Nugroho, H. (2020). Dampak Covid-19 terhadap Industri Minyak dan Gas Bumi: Rekomendasi Kebijakan untuk Indonesia. The Indonesian Journal of Development Planning, 4(2), 166-176. 